\title{
Role of $T$ helper 17 cytokines in the tumour immune inflammation response of patients with laryngeal squamous cell carcinoma
}

\author{
WEI-JING TANG ${ }^{1}$, LEI TAO ${ }^{1}$, LI-MING LU², DI TANG ${ }^{1}$ and XIAO-LIN SHI ${ }^{1}$ \\ ${ }^{1}$ Department of Otolaryngology, Eye, Ear, Nose and Throat Hospital, Fudan University, Shanghai 200031; \\ ${ }^{2}$ Shanghai Institute of Immunology, Shanghai Jiaotong University School of Medicine, Shanghai 200025, P.R. China
}

Received September 6, 2015; Accepted February 13, 2017

DOI: $10.3892 / \mathrm{ol} .2017 .6253$

\begin{abstract}
Altered cytokine production can lead to immune dysfunction in patients with cancer. The present study investigated the expression of T helper (Th)17 cytokines in patients with laryngeal squamous cell carcinoma (LSCC) and their clinical significance in providing new therapeutic insights. The prevalence of Th17 cells and their receptors in patients with LSCC was studied using immunohistochemical analysis via tissue microarray technology. Flow cytometry was used to investigate the percentage of Th17 and Th1 cells in peripheral blood mononuclear cells. Furthermore, the proliferation of Th17 cells and Th17-associated cytokines, including interleukin (IL)17, IL23 and RAR-related orphan receptor $\gamma \mathrm{t}$, was analyzed by reverse transcription-quantitative polymerase chain reaction. The results revealed that the prevalence of Th17 cells in patients with LSCC was elevated in their primary tumors, as well as in peripheral blood, compared with that in healthy controls. It was further demonstrated that Th17 cells could be induced and expanded in the tumor microenvironment through cytokines produced by the tumor cells. In conclusion, Th17 cells have a substantial impact on the carcinogenesis of LSCCs, and could serve as a potential therapeutic target to modulate the anti-tumor response in these carcinomas.
\end{abstract}

\section{Introduction}

Laryngeal carcinoma is the 11th most common form of cancer in humans worldwide (1). Pathologically, $>95 \%$ of all laryngeal malignancies are squamous cell carcinomas (SCCs) (2). It has been reported that $>75 \%$ of cases of laryngeal SCC (LSCC)

Correspondence to: Professor Lei Tao, Department of Otolaryngology, Eye, Ear, Nose and Throat Hospital, Fudan University, 83 Fenyang Road, Shanghai 200031, P.R. China

E-mail: doctortaolei@163.com

Professor Li-Ming Lu, Shanghai Institute of Immunology, Shanghai Jiaotong University School of Medicine, 280 South Chongqing Road, Shanghai 200025, P.R. China

E-mail: lulunew2003@163.com

Key words: Th17, LSCC, IL17, IL23, ROR $\gamma$ t, tumor microenvironment are attributable to cigarette smoking and alcohol consumption. Cigarette smoking is associated with an increased risk of LSCC compared with that of individuals who have never smoked, and heavy alcohol intake is an independent risk factor of LSCC (3). LSCC remains difficult to treat; furthermore, treatment can cause severe long-term side effects. For patients who are not cured by surgery and/or chemo-radiotherapy, there are few effective treatment options (4). Thus, targeted therapies and predictive biomarkers are urgently required in the perspective of LSCCs to improve the management and minimize the treatment toxicity, as well as to allow the selection of patients who are likely to benefit from both non-selective and targeted therapies (5).

Previous studies have confirmed that tumor immune inflammation is important in the tumor microenvironment (6). Cluster of differentiation (CD) $4^{+} \mathrm{T}$ cells are essential organizers of cell-mediated immunity, participating in each stage of the immune response. It has been confirmed that naïve (uncommitted) $\mathrm{CD}^{+} \mathrm{T}$ cells can be induced to different specific lineages according to the local cytokine, including towards T helper (Th)1, Th2, Th17 and T regulatory (Treg) cells (7). Interleukin (IL)17-producing Th17 cells, which are different from Th1 and Th2 cells, have been described as serving critical roles in inflammation and autoimmune diseases, as well as in cancer development (8-11). Considering these facts, it could be concluded that pro-inflammatory Th17 cells may have extensive effects on LSCC pathogenesis and anti-tumor response.

The present study revealed that patients with LSCC have elevated levels of Th17 cells in their primary tumors and peripheral blood compared with those in healthy controls. In addition, the LSCC microenvironment was identified as a strong Th17-cell inducer.

\section{Materials and methods}

Study subjects. A total of 70 tumors and 70 adjacent control tissues (pathologically confirmed normal mucosa) were obtained from patients with LSCC undergoing surgery. Peripheral blood was obtained from another 36 patients with LSCC and from 16 healthy individuals, who served as controls. The patients were registered for treatment at the Eye, Ear, Nose and Throat Hospital of Fudan University (Shanghai, China) from September 2013 to January 2015. For LSCC samples, patients with a known history of LSCC were enrolled, and malignancy was assessed by a pathological examination of the biopsies. The tumor staging of 

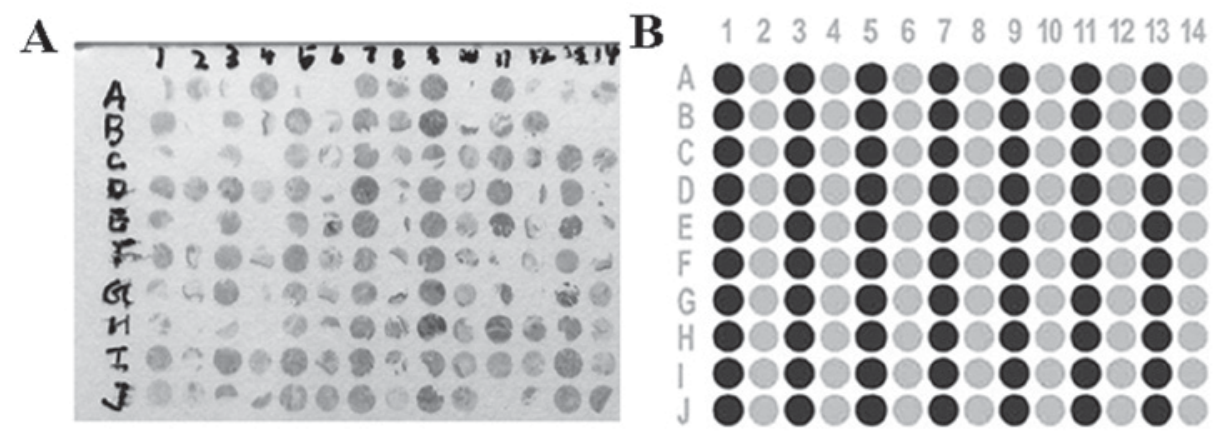

Tumours
Controls

Figure 1. Multitumor TMA. (A) Section containing 70 tumors and 70 adjacent tissues samples. The diameter of each tissue spot is $0.6 \mathrm{~mm}$. (B) Schematic layout of the TMA section. TMA, tissue microarray.

the patients was performed in accordance with the American Joint Committee on Cancer tumor-node metastasis (TNM) classification (12). All donors participated on a voluntary basis and provided written informed consent. The protocol was approved (no. KJ2008-01) by the ethics committee of the Eye, Ear, Nose and Throat Hospital of Fudan University (Shanghai, China) and was in agreement with this institutions ethical guidelines.

Tissue microarray (TMA) construction. TMA technology is a method where a large number of tissue samples are placed on a microscopic glass slide, which facilitates the transition from basic research to clinical applications (13). Briefly, the most representative tumor and adjacent tissue samples were selected in pairs. The corresponding areas of each donor paraffin blocks were perforated using a trephine needle (Quick Ray ${ }^{\circledR}$; Unitma Co., Ltd., Seoul, Korea) with a size of $1.5 \mathrm{~mm}$. The 1.5-mm-sized tissue cores were transferred and embedded into the recipient block with 140 empty 1.5 -mm-sized holes. All study specimens were obtained with both tumor and adjacent tissue samples from each donor block. Multiple 4- $\mu \mathrm{m}$-thick sections were cut with a microtome and transferred to poly-L-lysine-coated slides (\#22247-1; Hannotech Co., Ltd., Dongguan, China). TMA blocks were constructed, each containing one sample from all tumors and adjacent tissues (Fig. 1).

Immunohistochemical staining. Two TMA blocks with 70 tumors and 70 adjacent tissues samples were used for immunostaining, followed by standard procedures for the avidin-biotin-peroxidase method (14). The following anti-human monoclonal antibodies were used: Rabbit anti-IL17 (\#bs-2140R; BIOSS, Beijing, China) and rabbit anti-IL17A receptor (IL17R; \#bs-2606R; BIOSS). Briefly, the color reaction was developed with a 3,3'-diaminobenzidine solution at $20^{\circ} \mathrm{C}$ for $5 \mathrm{~min}$, and antibodies were diluted to 1:200 and incubated at $37^{\circ} \mathrm{C}$ for $1 \mathrm{~h}$. The cells were counterstained with hematoxylin.

The slices were evaluated by two pathologists without knowledge of the clinical outcome. The percentage of immunoreactive cells was graded on a scale of 0 to 4 , as follows: No staining was scored as $0 ; 1-10 \%$ of stained cells was scored as $1 ; 11-50 \%$ of stained cells was scored as $2 ; 51-80 \%$ of stained cells was scored as 3; and $81-100 \%$ of stained cells was scored as 4 . The staining intensities were graded from 0 to 3 , as follows: 0 was defined as negative; 1 as weak; 2 as moderate; and 3 as strong. The raw data were converted into an immunohistochemical score (IHS) by multiplying the quantity and intensity scores. An IHS score of 9-12 was considered to represent strong immunoreactivity $(+++) ; 5-8$ was considered as moderate $(++)$; 1 -4 was considered as weak $(+)$; and 0 was considered as negative immunoreactivity (-). On the final analysis, the cases that had an IHS $<1$ were considered as negative, and those with an IHS $\geq 1$ were regarded as positive.

Flow cytometry. Peripheral blood mononuclear cells (PBMCs) were isolated from $5 \mathrm{ml}$ of freshly obtained peripheral blood by centrifugation $\left(800 \mathrm{x} \mathrm{g}, 20^{\circ} \mathrm{C}, 20 \mathrm{~min}\right)$ on a Ficoll Hypaque density gradient (Ficoll PM 400; Sigma-Aldrich; Merck KGaA, Darmstadt, Germany). Prior to intracellular staining, the isolated PBMCs were stimulated for $5 \mathrm{~h}$ with $2 \mu \mathrm{l} / \mathrm{ml}$ Cell Stimulation Cocktail (\#00-4970; eBioscience, Inc., San Diego, CA, USA), a cocktail of phorbol 12-myristate 13-acetate (PMA; eBioscience, Inc.) and ionomycin (eBioscience, Inc.) in the presence of Protein Transport Inhibitor Cocktail (\#560751; BD Biosciences, Franklin Lakes, NJ, USA). Briefly, cells were fixed and permeabilised using the BD Cytofix/Cytoperm ${ }^{\mathrm{TM}}$ Buffer (Fixation and Permeabilization Solution; \#560751; BD Biosciences) according to manufacturer's protocol. Subsequently, the isolated PBMCs were intracellularly stained with the Human Th1/Th2/Th17 Phenotyping Cocktail (560751; BD Biosciences). Flow cytometry was performed on a BD FACSCalibur (BD Biosciences) and the data were evaluated using FlowJo software version 7.6.1 (TreeStar, Inc., Ashland, OR, USA). To determine the percentage of Th17 and Th1 cells, lymphocytes were gated by plotting forward vs. side scatter followed by gating on $\mathrm{CD} 4^{+} \mathrm{T}$ cells. The gated cells were then analyzed for IL-17A as phycoerythrin and interferon (IFN) $-\gamma$ as fluorescein isothiocyanate expression.

Reverse transcription-quantitative polymerase chain reaction $(R T-q P C R)$. Total RNA was extracted from patients' frozen tissues using TRIzol reagent (15596-018; Thermo Fisher Scientific, Inc., Waltham, MA, USA) according to the manufacturer's protocol. Complementary DNA (cDNA) was synthesized from $1 \mu \mathrm{g}$ total RNA in a 20- $\mu$ l reaction system using PrimeScript RT Reagent kit (Perfect Real Time; DRR063A; Takara, Bio, Inc., Otsu, Japan). The cDNA was then diluted with sterile water and stored at $-20^{\circ} \mathrm{C}$. The RT procedure using the PrimeScript RT Reagent kit was performed according to the manufacturer's protocol. 
Table I. Characteristic features of the patients in the current study.

\begin{tabular}{|c|c|c|c|}
\hline Characteristics & $\begin{array}{l}\text { Patients (fresh tissue) } \\
\quad(n=70), n(\%)\end{array}$ & $\begin{array}{l}\text { Patients (blood) } \\
(\mathrm{n}=36), \mathrm{n}(\%)\end{array}$ & $\begin{array}{l}\text { Controls (blood) } \\
\quad(n=16), n(\%)\end{array}$ \\
\hline \multicolumn{4}{|l|}{ Age, years } \\
\hline Mean (range) & $60.63(38-84)$ & $59.10(43-73)$ & $59.50(52-72)$ \\
\hline \multicolumn{4}{|l|}{ Sex } \\
\hline Male & $69(98.57)$ & $36(100.00)$ & $16(100.00)$ \\
\hline Female & $1(1.43)$ & $0(0.00)$ & $0(0.00)$ \\
\hline \multicolumn{4}{|l|}{ Site } \\
\hline Supraglottic & $23(32.86)$ & $6(16.67)$ & \\
\hline Glottic & $40(57.14)$ & $26(72.22)$ & \\
\hline Infraglottic & $7(10.00)$ & $4(11.11)$ & \\
\hline \multicolumn{4}{|l|}{ cT stage } \\
\hline $\mathrm{T}_{1}+\mathrm{T}_{2}$ & $17(24.29)$ & $25(69.44)$ & \\
\hline $\mathrm{T}_{3}+\mathrm{T}_{4}$ & $53(75.71)$ & $11(30.56)$ & \\
\hline \multicolumn{4}{|l|}{ pN stage } \\
\hline $\mathrm{N}_{0}$ & $33(47.14)$ & $31(86.11)$ & \\
\hline $\mathrm{N}_{1}+\mathrm{N}_{2}$ & $37(52.86)$ & $5(13.89)$ & \\
\hline \multicolumn{4}{|l|}{ Clinical stage } \\
\hline Early stage (I+II) & $6(8.57)$ & $26(72.22)$ & \\
\hline Late stage (III+IV) & $64(91.43)$ & $10(27.78)$ & \\
\hline \multicolumn{4}{|l|}{ Smoking history } \\
\hline Smokers & $62(88.57)$ & $25(69.44)$ & \\
\hline Non-smokers & $8(11.43)$ & $11(30.56)$ & \\
\hline \multicolumn{4}{|l|}{ Alcohol consumption } \\
\hline Drinkers & $34(48.57)$ & $17(47.22)$ & \\
\hline Non-drinkers & $36(51.43)$ & $19(52.78)$ & \\
\hline
\end{tabular}

RT-qPCR for IL17, IL23 and RAR-related orphan receptor (ROR) $\gamma$ t was performed on an Applied Biosystems 7500 Fast Real-Time PCR System (Thermo Fisher Scientific, Inc.), and the data were analyzed using the Applied Biosciences Real-Tiem PCR system 7500 software version 2.0.6 (Applied Biosystems; Thermo Fisher Scientific, Inc.). In brief, $2 \mu 1$ cDNA was added to a $20-\mu 1$ reaction mixture containing $10 \mu 1$ $2 X$ SYBR Premix Ex Taq, $0.4 \mu 1$ forward primer $(10 \mu \mathrm{M})$, $0.4 \mu 1$ reverse primer $(10 \mu \mathrm{M}), 0.4 \mu \mathrm{l}$ ROX reference dye and $6.8 \mu \mathrm{l}$ sterile water (all \#DRR063A; Takara, Bio, Inc., Otsu, Japan). All primers were designed using the Primer Premier version 5.0 software (Premier Biosoft International, Palo Alto, CA, USA), with their specificity confirmed by the Basic Local Alignment Search Tool on the National Center for Biotechnology Information website (http://blast.ncbi.nlm. nih.gov/Blast.cgi). Detailed information on the aforementioned primers is as follows: IL-17, forward 5'-TCCCACGAA ATCCAGGATGC-3' and reverse 5'-GGATGTTCAGGTTGA CCATCAC-3'; IL-23, forward 5'-TGCTCCCTGATAGCC CTGTGG-3' and reverse 5'-GCTGGGACTGAGGCTTGG AAT-3'; and ROR $\gamma$ t, forward 5'-GTGGGGACAAGTCGT CTGG-3' and reverse 5'-AGTGCTGGCATCGGTTTCG-3'. The PCR conditions were: $95^{\circ} \mathrm{C}$ for $30 \mathrm{sec}$, followed by 40 cycles at $95^{\circ} \mathrm{C}$ for $5 \mathrm{sec}$ and $60^{\circ} \mathrm{C}$ for $25 \mathrm{sec}$. All samples were processed in triplicate. The experiment was repeated for three times.
Relative gene expression was calculated using the comparative quantification cycle $(\mathrm{Cq})$ method (15). The messenger RNA expression levels of the target genes were normalized by $\beta$-actin, and the $2^{-\Delta \mathrm{Cq}}$ values were represented. For data analysis, the $2^{-\Delta \mathrm{Cq}}$ method was used to calculate the fold-change in expression, in which $\Delta \mathrm{Cq}$ represented the difference between the $\mathrm{Cq}$ value of the target gene and that of $\beta$-actin $\left(\mathrm{Cq}_{\text {target gene }}-\mathrm{Cq}_{\beta \text {-actin }}\right)$.

Statistical analysis. The data were reported as the mean \pm standard deviation or the mean \pm standard error. IL-17 and IL-17R expression in tumors and adjacent tissues was evaluated by $\chi^{2}$ test. The percentage of Th17 and Th17/Th1 cells in the peripheral blood of patients with cancer compared with that of healthy controls was assessed using t-tests. Cytokines IL17, IL23 and ROR $\gamma$ t in LSCC tissues compared with that of non-cancerous tissues were assessed using one-way analysis of variance. All statistical calculations were performed using SPSS version 19 (IBM SPSS, Armonk, NY, USA). P<0.05 was considered to indicate a statistical significant difference.

\section{Results}

Descriptive features of the study groups. Table I shows the descriptive characteristics of the study subjects, comprising 


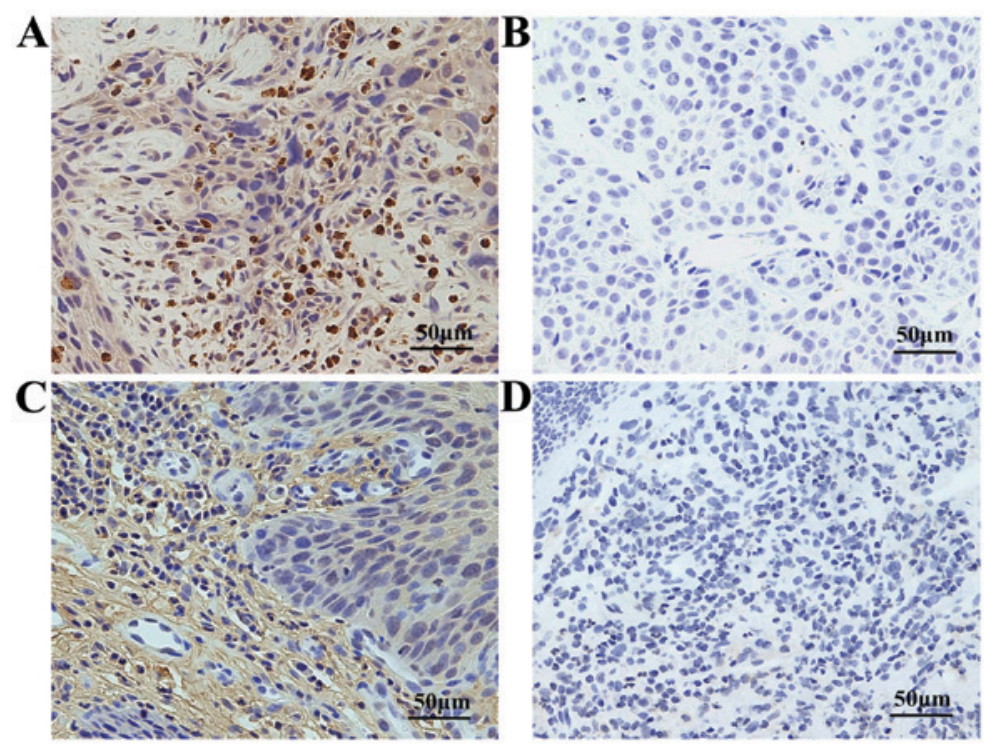

Figure 2. Positive and negative expression of IL17/IL17R immunohistochemistry in tissue microarray sections. (A) Positive and (B) negative expression of IL17. (C) Positive and (D) negative expression of IL17R. Original magnification, x20. IL, interleukin; R, receptor.

Table II. Positive results of IL17/IL17R immunohistochemistry in tumors and controls.

\begin{tabular}{lccc}
\hline Molecule & $\begin{array}{c}\text { Tumors, } \\
\mathrm{n}(\%)\end{array}$ & $\begin{array}{c}\text { Controls, } \\
\mathrm{n}(\%)\end{array}$ & P-value \\
\hline IL17 & $57(81.43)$ & $26(37.14)$ & $<0.05$ \\
IL17R & $64(91.43)$ & $49(70.00)$ & $<0.05$ \\
\hline
\end{tabular}

IL, interleukin; R, receptor.

116 patients with LSCC and 16 healthy controls. Pathologically, all patients had SCC. Of a total of 116 patients, 115 patients $(99.14 \%)$ were males and only $1(0.86 \%)$ was female. The control group had a similar sex distribution, including 16 males $(100.00 \%)$.

Immunohistochemical observations. To study the expression of IL17 and IL17R in vivo, the tumors and adjacent tissues were stained for IL17 and IL17R using immunohistochemistry (Fig. 2). Differential IL-17 and IL-17R expression in tumors and adjacent tissues was confirmed.

Overall, positive staining for IL17 was noted in 57 (81.43\%) of 70 tumors with the following scores: $0,13(18.57 \%)$ of 70 ; $1-4,16(22.86 \%)$ of $70 ; 5-8,27(38.57 \%)$ of 76; and 9-12, 14 $(20.00 \%)$ of 70 samples. Among the controls, positive staining for IL17 was noted in $26(37.14 \%)$ of 70 samples. IL17R positive staining was observed in $64(91.43 \%)$ of 70 cases. These included $0,6(8.57 \%)$ of $70 ; 1-4,22(31.43 \%)$ of $70 ; 5-8,28$ (40.00\%) of 70; and 9-12, $14(20.00 \%)$ of 70 cases. Among the controls, positive staining for IL17R was noted in 49 (70.00\%) of 70 samples (Table II).

Elevated levels of Th17 cells in the peripheral blood of patients with LSCC. The prevalence of Th17 cells in the peripheral blood of 36 patients with LSCC was compared with that of
16 healthy controls to address whether there was an increased prevalence of Th17 cells in patients with LSCC. PBMCs were isolated and stimulated with PMA and ionomycin for $5 \mathrm{~h}$ in the presence of Protein Transport Inhibitor, and Th17 and Th1 cells were next quantified by flow cytometry. Th17 cells were identified as a CD $4^{+} \mathrm{IL} 17^{+}$cell population. Th1 cells were identified as a $\mathrm{CD} 4^{+} \mathrm{IFN}-\gamma^{+}$cell population. As shown in Figs. 3 and 4A, there was a statistically significantly higher percentage of Th17 cells in the peripheral blood of patients with cancer $(1.6860 \pm 0.1866 \%, \mathrm{n}=36)$ compared with that of healthy controls $(0.4963 \pm 0.7862 \%, \mathrm{n}=16 ; \mathrm{P}<0.05)$.

Th17/Th1 cells are increased in the peripheral blood of patients with LSCC. Th17/Th1 cells, which simultaneously produce the Th17 cytokine IL17 and the Th1 cytokine IFN- $\gamma$ (16), accounted for $\sim 3.714 \%$ in healthy individuals $(3.714 \pm 0.3487 \%$; $\mathrm{n}=16)$. In the peripheral blood of patients with LSCC, this subpopulation was significantly increased $(21.03 \pm 1.750 \%$; $\mathrm{n}=36$; $\mathrm{P}<0.05$; Fig. 4B).

Upregulation of intracellular cytokines IL17, IL23 and ROR $\gamma t$ in Th17 cells. RT-qPCR revealed that the Th17-associated intracellular cytokines and transcription factors IL17, IL23 and ROR $\gamma \mathrm{t}$ in LSCC tissues were upregulated compared with their levels in matched adjacent non-cancerous tissues (Fig. 5). This indicated that Th17 cells expanded in the LSCC tissue cell population, and may be involved in LSCC development and metastasis.

\section{Discussion}

Tumors grow in a complex and active microenvironment. Within or nearby the tumor nests, lymphocytes as well as endothelial, stromal and innate cells are present, which interact with each other to form the tumor microenvironment (17). Inflammation is causally associated with cancer development through processes that involve genotoxicity, aberrant tissue repair, proliferative responses, invasion and metastasis (17). 

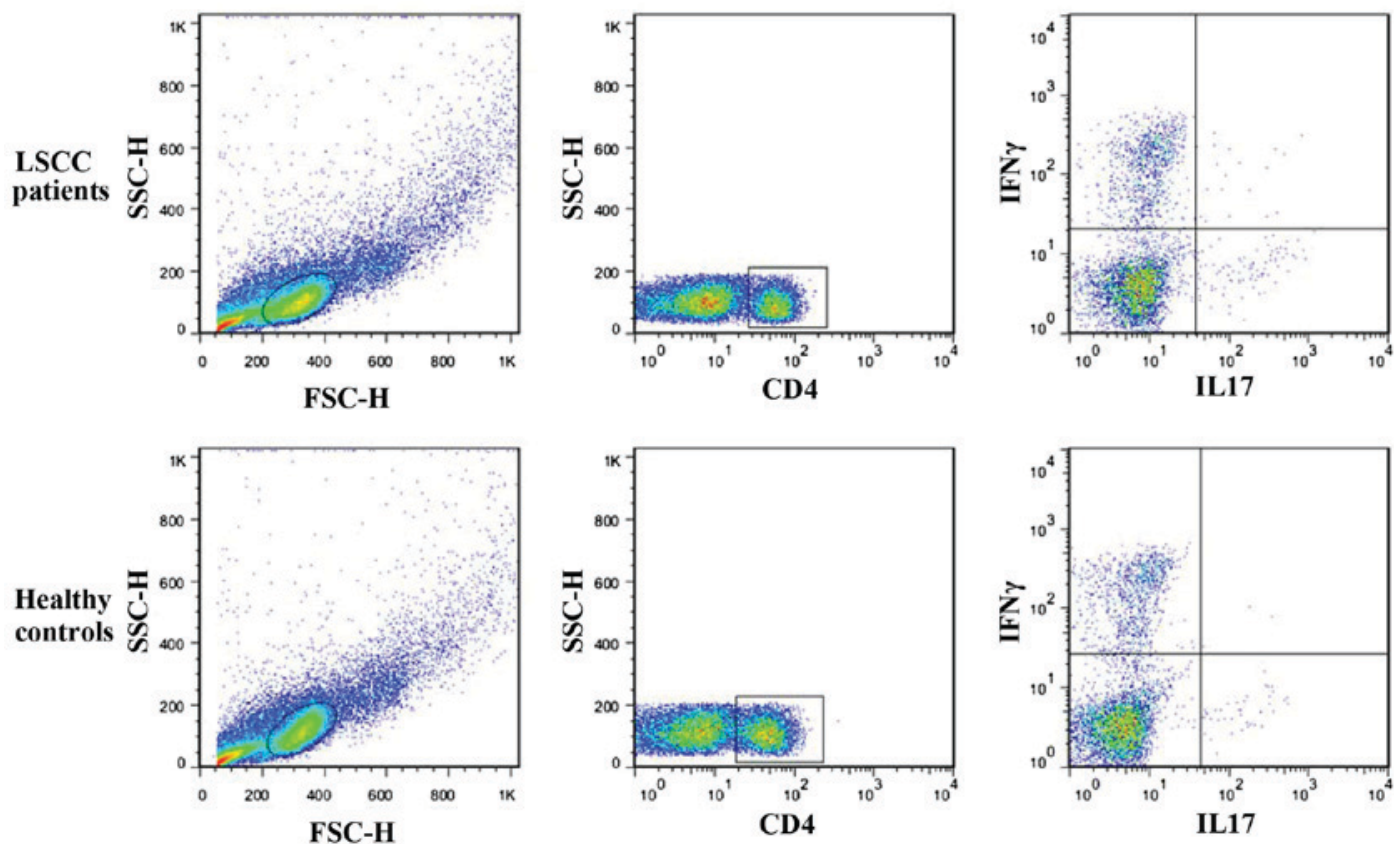

Figure 3. Levels of Th17 and Th1 cells in peripheral blood mononuclear cells from patients with LSCC and healthy controls. SCC, side scatter; FSC, forward scatter; Th, T helper; LSCC, laryngeal squamous cell carcinoma; CD, cluster of differentiation; IL, interleukin; IFN, interferon; H, height.
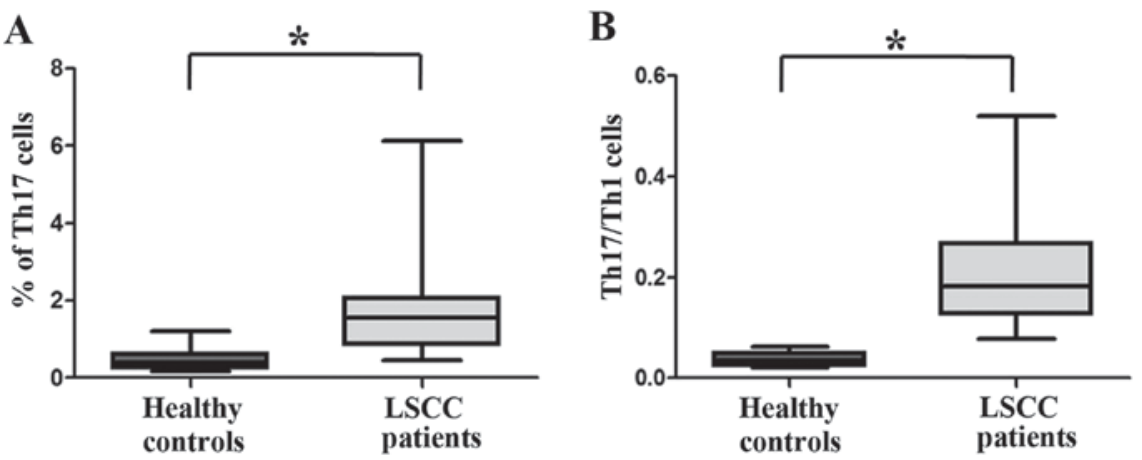

Figure 4. Prevalence of Th17 and Th17/Th1 cells in the peripheral blood of patients with LSCC and healthy controls. (A) Comparison of the prevalence of Th17 cells in the peripheral blood of healthy controls and patients with LSCC ( $\mathrm{P}<0.05)$. The data are expressed as the frequency of Th17 cells in the lymphocyte population. The box plots show the median (middle line), 25th and 75th percentiles (box, and the extreme values (whiskers). (B) Prevalence of Th17/Th1 cells in the peripheral blood of patients with LSCC compared with that in healthy controls with ( $\mathrm{P}<0.05$ ). The box plots show the median (middle line), 25th and 75th percentiles (box), and the extreme values (whiskers). Th, T helper; LSCC, laryngeal squamous cell carcinoma.

Tumors modulate the inflammatory environment through the secretion of soluble growth factors and chemoattractants, which render inflammatory cells suppressive against anti-cancer $\mathrm{T}$ cell responses (17). $\mathrm{CD} 4^{+} \mathrm{Th}$ cells, as a highly heterogeneous population, serve critical roles in tumor immunological responses (18). Initially, immunologists considered that $\mathrm{CD}^{+} \mathrm{T}$ cells mainly included two types, namely $\mathrm{Th} 1$ and Th2 (19); however, at least four distinct $\mathrm{CD}^{+} \mathrm{T}$ cell subsets have been confirmed to exist, specifically Th1, Th2, Th17 and Treg cells (19).

LSCCs produce various immunosuppressive and tumor-promoting cytokines, leading to an impaired anti-tumor response (20). In previous cytogenetic studies, it was observed that multiple signaling pathways were activated in LSCC, including the $\mathrm{p} 53$, vascular endothelial growth factor, epidermal growth factor receptor, transforming growth factor (TGF)- $\beta$ and nuclear factor- $\mathrm{\kappa}$ B signaling pathways (21). In addition, it has been well established that inflammation is closely connected to LSCC development due to the induction of chronic inflammation caused by exposure to irritants in inhaled air, particularly cigarette smoke. Such irritants enhance the accumulation of viruses and airborne microbes, thereby promoting tumor growth (22). Considering these facts, it can be concluded that pro-inflammatory Th17 cells have extensive effects on LSCC pathogenesis and anti-tumor response.

It was previously shown that Th17 cells are involved in tissue inflammation by inducing the release of various cytokines, including IL6, IL21, IL23, IL1 $\beta$ and TGF- $\beta$, by neighboring tumor cells, tumor-derived fibroblasts and antigen-presenting cells (23). Human Th17 cells mainly release the pro-inflammatory cytokine IL17, and one important role of IL17 appears to be the regulation of local inflammation through the upregulation of other pro-inflammatory cytokines and chemokines (24). In this regard, it is reasonable to propose 


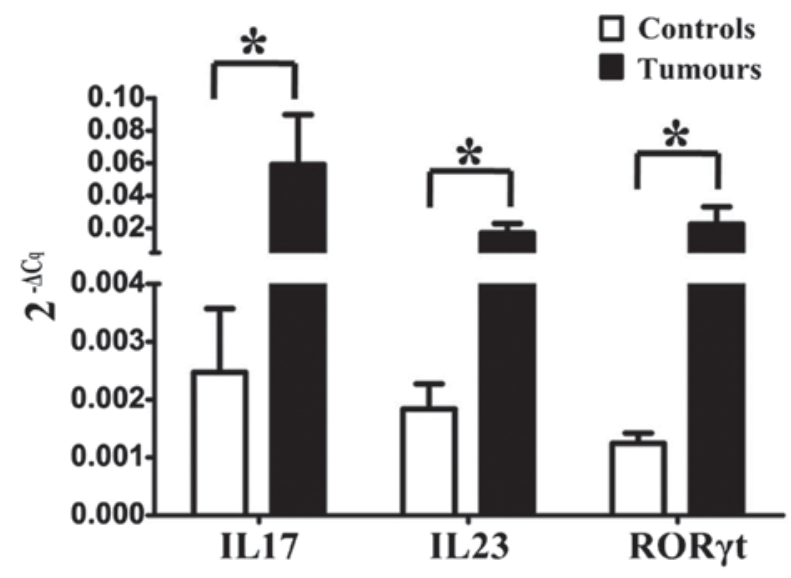

Figure 5. Reverse transcription-quantitative polymerase chain reaction analysis of the Th17-associated intracellular cytokines and transcription factors IL17, IL23 and ROR $\gamma$ t in tumors and controls. ${ }^{*} \mathrm{P}<0.05$. IL, interleukin; ROR, RAR-related orphan receptor; $\mathrm{Cq}$, quantification cycle.

the impact of Th17 cells on cancer pathogenesis and progression. In gastric cancer, there was both an elevation of Th17 frequency in peripheral blood and tumor-draining lymph nodes (25). Furthermore, in ovarian cancer, it was shown that Th17 cells were increased in tumor tissue, but not in peripheral blood (15). However, the function of Th17 cells and their influence on LSCC development in humans remain unknown.

Several studies demonstrated that human Th17 cells produce IL17A and exhibit ROR $\gamma$ t expression $(26,27)$. These cells also express IL17R, which is also expressed by Th1 cells $(26,27)$. Human Th17 cells appear to exclusively originate from a small subset of T-cell precursors, which constitutively express ROR $\gamma$ t and IL-17R, and develop into Th17 cells in response to IL1 $\beta$ and IL23 in the apparent absence of TGF- $\beta$ (28). Furthermore, even established Th17 cells can be induced to produce IFN- $\gamma$ in addition to IL17A (Th17/Th1 cells), suggesting a common developmental association between Th17 and at least a subset of Th1 cells (28). Notably, numerous studies have reported increased expression of IL17/Th17 cells in different cancers, including colorectal (29), prostate (30), gastric (31), lung (32), ovarian (33), oral (34) and head and neck (35) carcinomas.

The present study revealed that patients with LSCC have elevated levels of Th17 cells in their primary tumors and peripheral blood compared with those exhibited by healthy controls. The LSCC microenvironment was identified as a strong Th17-cell inducer. First, histopathological characterization was performed, and immunohistochemistry staining was used to detect IL17 and IL17R expression in patients with LSCC. Overexpression of both IL17 and IL17R was observed in tumors compared with the expression detected in adjacent tissues. Next, whether Th17 cells have any functional implications for LSCC development was evaluated. The frequencies of Th17 and Th1 cells in the peripheral blood of patients with LSCC were investigated, and a higher percentage of Th17 cells was detected in the peripheral blood of patients with LSCC compared with that in healthy controls. No association was observed between TNM staging and Th17 cell frequency, which suggests that Th17 cells were consistently elevated in patients with LSCC, independently of tumor stage. This may represent a link between inflammation and cancer; however, the exact mechanisms by which elevated levels of pro-inflammatory Th17 cells and the resultant secretion of cytokines contribute to inflammatory processes in cancer remain to be elucidated.

The present study demonstrated that Th17 cells can be induced by PBMCs of patients with LSCC. Upon incubation of isolated naïve $\mathrm{CD}^{+}{ }^{+} \mathrm{T}$ cells in LSCC PBMCs in vitro, a significantly elevated number of Th17 cells was detected. Therefore, it can be proposed that the LSCC microenvironment is able to induce a Th17 lineage commitment. It was also observed that Th1 cells were downregulated in peripheral blood. It is known that Th1 cytokines, such as IFN- $\gamma$, are diminished in LSCC (36), whereas IL17 is upregulated; thus, this may be the mechanism responsible for Th17 and Th1/Th17 cell modulation in LSCC. However, the outcome of these Th1/Th17 cells under tumor influence (whether they simply attenuate their IFN- $\gamma$ secretion or change into another T-cell population) remains to be investigated. Our hypothesis is that Th1 cells are functionally modulated by the tumor microenvironment and are converted into Th17 cells.

RT-qPCR demonstrated that the levels of Th17-associated intracellular cytokines and transcription factors (including IL17, IL23 and ROR $\gamma$ t) of LSCC tissue were upregulated. Since it was shown that IL23 and ROR $\gamma$ t lead to Th17 expansion (37), as well as to selective enrichment of IL17-producing cells by modulating the proliferation of memory $\mathrm{T}$ cells (38), the present study was able to show that IL23 and ROR $\gamma$ t levels in LSCC lead to a strong enhancement of Th17 cell expansion directly at the tumor site. There have been different reports about the influence of Th17 on tumor progression, a number of which depict a positive influence of Th17 on tumor proliferation $(39,40)$, while others describe an inhibitory influence on tumor growth $(41,42)$. Ciree et al (43) demonstrated that Th17 cells are upregulated in the T-cell lymphomas mycosis fungoides and Sézary syndrome, and may act as a tumor growth-promoting or -inhibiting factor. In addition, the authors observed an association between Th17 expression and polymorphonuclear neutrophil infiltration. Muranski et al (44) reported that Th17 cells in a mouse model were able to eradicate melanomas. This association was affirmed by Garcia-Hernandez et al (45); in their description, neutrophils were attracted to the tumor microenvironment by a Th17-dependent mechanism, and indicated that depletion of neutrophils resulted in a diminished capacity to control tumor growth. In addition, Honorati et al (46) reported an increased susceptibility of osteosarcoma cells to natural killer cells under the influence of Th17.

Altogether, the present study demonstrated that Th17 cells are highly present in LSCC. However, this appears to act as a double-edged sword: On one hand, Th17 cells accelerate metastasis and appear to be, therefore, beneficial to tumors; on the other hand, Th17 cells appear to be beneficial to the host due to their proliferation-reducing activity. Therefore, it is important to study the function of Th17 cells in malignant diseases in depth, and to attempt to elucidate their mechanism of action and their modulation by the tumor microenvironment. The present results raise a further issue to investigate, namely whether Th17 cells express different molecules or secrete different cytokines in patients with LSCC compared with those in healthy individuals. Future studies should 
consider whether Th17 cells can recognize tumor cells and if they are at all able to impair tumor growth or metastasis in vivo; in addition, their exact potential mechanism of action must be elucidated.

\section{Acknowledgements}

The present study was supported by the National Natural Science Foundation of China (grant nos. 30801283 and 30972691), the Shanghai Science and Technology Development Funds (grant nos. 09QA1401000, 10QA1405900 and 14411961900), the Training Program of the Excellent Young Talents of the Shanghai Municipal Health System (grant nos. XYQ2011055 and XYQ2011015) and the Shanghai Municipal Science and Technology Foundation (grant no. 11JC1410802).

\section{References}

1. Marioni G, Marchese-Ragona R, Cartei G, Marchese F and Staffieri A: Current opinion in diagnosis and treatment of laryngeal carcinoma. Cancer Treat Rev 32: 504-515, 2006.

2. Almadori G, Bussu F, Cadoni G, Galli J, Paludetti G and Maurizi M: Molecular markers in laryngeal squamous cell carcinoma: Towards an integrated clinicobiological approach. Eur J Cancer 41: 683-693, 2005.

3. Hashibe M, Brennan P, Benhamou S, Castellsague X, Chen C, Curado MP, Dal Maso L, Daudt AW, Fabianova E, Fernandez L, et al: Alcohol drinking in never users of tobacco, cigarette smoking in never drinkers and the risk of head and neck cancer: Pooled analysis in the International Head and Neck Cancer Epidemiology Consortium. J Natl Cancer Inst 99: 777-789, 2007.

4. Brandstorp-Boesen J, Falk RS, Boysen M and Brøndbo K: Long-term trends in gender, T-stage, subsite and treatment for laryngeal cancer at a single center. Eur Arch Otorhinolaryngol 271: 3233-3239, 2014

5. Suh Y, Amelio I, Guerrero Urbano T and Tavassoli M: Clinical update on cancer: Molecular oncology of head and neck cancer. Cell Death Dis 23: e1018, 2014.

6. Qi W, Huang X and Wang J: Correlation between Th17 cells and tumour microenvironment. Cell Immunol 285: 18-22, 2013.

7. Middleton GW, Annels NE and Pandha HS: Are we ready to start studies of Th17 cell manipulation as a therapy for cancer? Cancer Immunol Immunother 61: 1-7, 2012.

8. Ye J,Livergood RS and Peng G: The role and regulation of human Th17 cells in tumour immunity. Am J Pathol 182: 10-20, 2013.

9. Maddur MS, Miossec P, Kaveri SV and Bayry J: Th17 cells: Biology, pathogenesis of autoimmune and inflammatory diseases, and therapeutic strategies. Am J Pathol 181: 8-18, 2012.

10. Wilke CM, Bishop K, Fox D and Zou W: Deciphering the role of Th17 cells in human disease. Trends Immunol 32: 603-611, 2011.

11. Kimura $A$ and Kishimoto T: Th17 cells in inflammation. Int Immunopharmacol 11: 319-322, 2011.

12. Paleri V, Mehanna H and Wight RG: TNM classification of malignant tumours 7th edition: What's new for head and neck? Clin Otolaryngol 35: 270-272, 2010.

13. Torhorst J, Bucher C, Kononen J, Haas P, Zuber M, Köchli OR, Mross F, Dieterich H, Moch H, Mihatsch M, et al: Tissue microarrays for rapid linking of molecular changes to clinical endpoints. Am J Pathol 159: 2249-2256, 2001

14. Vosse BA, Seelentag W, Bachmann A, Bosman FT and Yan P: Background staining of visualization systems in immunohistochemistry: Comparison of the Avidin-Biotin Complex system and the EnVision+ system. Appl Immunohistochem Mol Morphol 15: 103-107, 2007

15. Miyahara Y, Odunsi K, Chen W, Peng G, Matsuzaki J and Wang RF: Generation and regulation of human CD4+ IL-17-producing T cells in ovarian cancer. Proc Natl Acad Sci USA 105: 15505-15510, 2008.

16. Llosa NJ, Geis AL, Thiele Orberg E and Housseau F: Interleukin-17 and type 17 helper T cells in cancer management and research. Immunotargets Ther 3: 39-54, 2014

17. Elinav E, Nowarski R, Thaiss CA, Hu B, Jin C and Flavell RA: Inflammation-induced cancer: Crosstalk between tumours, immune cells and microorganisms. Nat Rev Cancer 13: 759-771, 2013.
18. Zhu J and Paul WE: Heterogeneity and plasticity of T helper cells. Cell Res 20: 4-12, 2010.

19. Zhu J and Paul WE: CD4 T cells: Fates, functions, and faults. Blood 112: 1557-1569, 2008.

20. Johnson SD, De Costa AM and Young MR: Effect of the premalignant and tumour microenvironment on immune cell cytokine production in head and neck cancer. Cancers (Basel) 6: 756-770, 2014.

21. Görögh T and Beier UH: Gene alterations in head and neck carcinomas and their role in promoting malignant behavior (Review). Int J Oncol 36: 525-532, 2010.

22. Douglas WG, Tracy E, Tan D, Yu J, Hicks WL Jr, Rigual NR, Loree TR, Wang Y and Baumann H: Development of head and neck squamous cell carcinoma is associated with altered cytokine responsiveness. Mol Cancer Res 2: 585-593, 2004.

23. Chung Y, Chang SH, Martinez GJ, Yang XO, Nurieva R, Kang HS, Ma L, Watowich SS, Jetten AM, Tian Q and Dong C: Critical regulation of early Th17 cell differentiation by interleukin-1 signaling. Immunity 30: 576-587, 2009.

24. Park H, Li Z, Yang XO, Chang SH, Nurieva R, Wang YH, Wang Y, Hood L, Zhu Z, Tian Q and Dong C: A distinct lineage of $\mathrm{CD} 4 \mathrm{~T}$ cells regulates tissue inflammation by producing interleukin 17. Nat Immunol 6: 1133-1141, 2005.

25. Zhang B, Rong G, Wei H, Zhang M, Bi J, Ma L, Xue X, Wei G, Liu X and Fang G: The prevalence of Th17 cells in patients with gastric cancer. Biochem Biophys Res Commun 374: 533-537, 2008.

26. Acosta-Rodriguez EV,Rivino L, Geginat J,Jarrossay D, Gattorno M, Lanzavecchia A, Sallusto F and Napolitani G: Surface phenotype and antigenic specificity of human interleukin 17-producing $\mathrm{T}$ helper memory cells. Nat Immunol 8: 639-646, 2007.

27. Annunziato F, Cosmi L, Liotta F, Maggi E and Romagnani S: The phenotype of human Th17 cells and their precursors, the cytokines that mediate their differentiation and the role of Th17 cells in inflammation. Int Immunol 20: 1361-1368, 2008.

28. Romagnani S, Maggi E, Liotta F, Cosmi L and Annunziato F: Properties and origin of human Th17 cells. Mol Immunol 47: 3-7, 2009.

29. Wägsäter D, Löfgren S, Hugander A and Dimberg J: Expression of interleukin-17 in human colorectal cancer. Anticancer Res 26: 4213-4216, 2006.

30. Sfanos KS, Bruno TC, Maris $\mathrm{CH}$, Xu L, Thoburn CJ, DeMarzo AM, Meeker AK, Isaacs WB and Drake CG: Phenotypic analysis of prostate-infiltrating lymphocytes reveals TH17 and Treg skewing. Clin Cancer Res 14: 3254-3261, 2008.

31. Zhang B, Rong G, Wei H, Zhang M, Bi J, Ma L, Xue X, Wei G, Liu X and Fang G: The prevalence of Th17 cells in patients with gastric cancer. Biochem Biophys Res Commun 374: 533-537, 2008.

32. Koyama K, Kagamu H, Miura S, Hiura T, Miyabayashi T, Itoh R, Kuriyama H, Tanaka H, Tanaka J, Yoshizawa H, et al: Reciprocal CD4+ T-cell balance of effector CD62Llow CD4+ and CD62LhighCD25+ CD4+ regulatory $\mathrm{T}$ cells in small cell lung cancer reflects disease stage. Clin Cancer Res 14: 6770-6779, 2008.

33. Kryczek I, Banerjee M, Cheng P, Vatan L, Szeliga W, Wei S, Huang E, Finlayson E, Simeone D, Welling TH, et al: Phenotype, distribution, generation, and functional and clinical relevance of Th17 cells in the human tumour environments. Blood 114: 1141-1149, 2009

34. Gaur P, Qadir GA, Upadhyay S, Singh AK, Shukla NK and Das SN: Skewed immunological balance between Th17 (CD4(+) IL17A (+)) and Treg (CD4 (+)CD25 (+)FOXP3 (+)) cells in human oral squamous cell carcinoma. Cell Oncol (Dordr) 35: 335-343, 2012.

35. Kesselring R, Thiel A, Pries R, Trenkle T and Wollenberg B: Human Th17 cells can be induced through head and neck cancer and have a functional impact on HNSCC development. Br J Cancer 103: 1245-1254, 2010.

36. Bose A, Chakraborty T, Chakraborty K, Pal S and Baral R: Dysregulation in immune functions is reflected in tumour cell cytotoxicity by peripheral blood mononuclear cells from head and neck squamous cell carcinoma patients. Cancer Immun 8: $10,2008$.

37. Chizzolini C, Chicheportiche R, Alvarez M, de Rham C, Roux-Lombard P, Ferrari-Lacraz S and Dayer JM: Prostaglandin E2 synergistically with interleukin-23 favors human Th17 expansion. Blood 112: 3696-3703, 2008

38. Napolitani G, Acosta-Rodriguez EV, Lanzavecchia A and Sallusto F: Prostaglandin E2 enhances Th17 responses via modulation of IL-17 and IFN-gamma production by memory CD4+ T cells. Eur J Immunol 39: 1301-1312, 2009. 
39. Benchetrit F, Ciree A, Vives V, Warnier G, Gey A, Sautès-Fridman C, Fossiez F, Haicheur N, Fridman WH and Tartour E: Interleukin-17 inhibits tumour cell growth by means of a T-cell-dependent mechanism. Blood 99: 2114-2121, 2002.

40. Numasaki M, Watanabe M, Suzuki T, Takahashi H, Nakamura A, McAllister F, Hishinuma T, Goto J, Lotze MT, Kolls JK and Sasaki H: IL-17 enhances the net angiogenic activity and in vivo growth of human non-small cell lung cancer in SCID mice through promoting CXCR-2-dependent angiogenesis. J Immunol 175: 6177-6189, 2005.

41. Nam JS, Terabe M, Kang MJ, Chae H, Voong N, Yang YA, Laurence A, Michalowska A, Mamura M, Lonning S, et al: Transforming growth factor beta subverts the immune system into directly promoting tumour growth through interleukin- 17 . Cancer Res 68: 3915-3923, 2008.

42. Kryczek I, Wei S, Szeliga W, Vatan L and Zou W: Endogenous IL-17 contributes to reduced tumour growth and metastasis. Blood 114: 357-359, 2009.
43. Ciree A, Michel L, Camilleri-Bröet S, Jean Louis F, Oster M, Flageul B, Senet P, Fossiez F, Fridman WH, Bachelez H and Tartour E: Expression and activity of IL-17 in cutaneous T-cell lymphomas (mycosis fungoides and Sezary syndrome). Int J Cancer 112: 113-120, 2004.

44. Muranski P, Boni A, Antony PA, Cassard L, Irvine KR, Kaiser A, Paulos CM, Palmer DC, Touloukian CE, Ptak K, et al: Tumour-specific Th17-polarized cells eradicate large established melanoma. Blood 112: 362-373, 2008 .

45. Garcia-Hernandez Mde L, Hamada H, Reome JB, Misra SK, Tighe MP and Dutton RW: Adoptive transfer of tumour-specific Tc17 effector T cells controls the growth of B16 melanoma in mice. J Immunol 184: 4215-4227, 2010.

46. Honorati MC, Neri S, Cattini L and Facchini A: IL-17 enhances the susceptibility of U-2 OS osteosarcoma cells to NK cell lysis. Clin Exp Immunol 133: 344-349, 2003. 